\title{
IMPLEMENTASI PERATURAN DESA NO. 3 TAHUN 2009 TERHADAP \\ KETERTIBAN PENYELENGGARAAN HAJATAN DI DESA SIRAPAN \\ KECAMATAN MADIUN KABUPATEN MADIUN TAHUN 2014
}

\author{
Soenarjo* \\ Mira**
}

\begin{abstract}
Abstrak
Dalam penyelenggaraan hajatan masyarakat Desa Sirapan kerap muncul gangguan atau kegaduhan yang dilakukan oleh orang tertentu yang tidak bertanggungjawab, membuat masyarakat ketika menyelenggarakan hajatan merasa tidak nyaman, tidak tentram, dan tidak damai. Serta dari keonaran atau kisruh tersebut juga menimbulkan kerugian yang harus ditanggung penyelenggara hajatan. Dengan adanya tindakan tersebut, maka kepala desa dan BPD membuat peraturan desa.

Untuk mewujudkannya semua elemen desa haruslah ikut berpartisipasi agar ketertiban yang diharapkan pada penyelenggaraan hajatan terwujud dan terlaksana dengan baik, yang mana aturannya terdapat pada Peraturan Desa nomor 3 tahun 2009 tentang ketertiban penyelenggaran hajatan.

Peneliti dalam penelitian ini menggunakan pendekatan metode deskriptif kualitatif. Penelitian akan dilakukan di lapangan (Field research) yang bersifat deskriptif kualitatif. Peraturan Desa Nomor 3 Tahun 2009 khususnya mengenai ketertiban penyelenggaraan hajatan telah di laksanaakan sesuai aturan sehingga tidak mengganggu ketertiban di dalam penyelenggaraan hajatan yang diadakan masyarakat Desa Sirapan.Hal ini dapat dibuktikan, bahwa setiap di laksanakannya penyelenggaraan hajatan di Desa Sirapan selalu berjalan dengan lancar dan tidak menimbulkan keributan-keributan yang dapat mengganggu ketenangan masyarakat Desa Sirapan saat menyelenggarakan hajatan. Sehingga, penyelenggaraan hajatan dapat berjalan dengan baik, tertib, lancar, dan aman serta keadaan menjadi kondusif dan terkendali. Ini disebabkan karena adanya kesadaran dan peran aktif masyarakat dalam pelaksanaan Peraturan Desa Nomor 3 tahun 2009 khususnya mengenai ketertiban penyelenggaraan hajatan dan kerjasama yang baik antara masyarakat Desa Sirapan dengan perangkat desa. Dengan demikian, tujuan dari ketertiban yakni terwujudnya rasa aman, tidak ada sengketa maupun tidak ada konflik dapat terwujud dan terlaksana dengan baik.
\end{abstract}

Kata kunci : Peraturan Desa, ketertiban masyarakat

*Dosen Prodi PPKn IKIP PGRI Madiun

** Mahasiswa Prodi PPKn IKIP PGRI Madiun 


\section{PENDAHULUAN}

Sesuai dengan UndangUndang Nomor 32 tahun 2004 tentang peraturan daerah, desa mempunyai wewenang mengatur dan mengurus urusan masyarakat setempat sesuai dengan asal usul adat istiadatnya. Dalam rangka mengatur urusan masyarakat setempat tersebut desa dapat membuat peraturan desa. Peraturan desa merupakan bentuk regulasi yang dikeluarkan pemerintah desa sebagaimana kabupaten membuat peraturan daerah. Landasan pemikiran dalam pengaturan mengenai desa adalah keanekaragaman partisipasi, otonomi asli, demokratisasi dan pemberdayaan masyarakat (Hanif Nurcholis, 2011:113).

Dipandang dari segi pemerintahan, desa merupakan bawahan dari kota. Selain itu secara struktural merupakan unit terendah di bawah kecamatan. Pemerintah desa merupakan representasi kepanjangan struktur pemerintah pusat. Pemerintah desa umumnya bukan pemerintahan yang mandiri, tetapi fokus penerapan kebijakan pemerintahan tingkat atasnya.
Pemerintah desa selalu diatur melalui berbagai perundang-undangan, peraturan pelaksana, dan kebijakan pemerintah pusat dan pemerintah daerah. Pemerintah desa dibentuk berdasarkan kelembagaan masyarakat desa dan bentuk serta fungsinya ditetapkan sesuai dengan keputusan atau ketetapan pemerintah yang lebih atas.

Menurut Undang-Undang nomor 22 tahun 1999 jo UndangUndang nomor 32 tahun 2004 desa tidak lagi dibawah kecamatan tapi di bawah kabupaten atau kota. Dengan demikian, kepala desa langsung di bawah pembinaan bupati atau walikota. Kecamatan bukan lagi sebagai suatu wilayah yang membawahi desa-desa tapi hanya merupakan wilayah kerja camat. Camat sendiri bukan kepala wilayah dan penguasa tunggal di wilayahnya, tapi hanya sebagai perangkat daerah kabupaten. Jadi, camat hanyalah staf daerah kabupaten yang mengurusi desa-desa. Di dalam Undang-Undang Nomor 22 tahun 1999 membedakan secara tegas peran Kepala Desa Dan Badan Permusyawaratan Desa (BPD). Kepala desa adalah pelaksana 
kebijakan sedangkan Badan

Permusyawaratan Desa atau BPD

adalah lembaga pembuat kebijakan

(Peraturan Desa). Badan

permusyawaratan desa atau BPD

mempunyai tugas salah satunya ialah

membuat peraturan desa bersama

Kepala Desa, peraturan desa jika di pemerintah daerah disebut peraturan daerah, sedangkan di tingkat negara disebut undang-undang (Hanif Nurcholis, 2005:235-236).

Peraturan desa ini ditetapkan oleh Kepala Desa bersama BPD. Peraturan desa dibentuk dalam rangka penyelenggaraan pemerintahan desa. Peraturan desa merupakan penjabaran lebih lanjut dari peraturan perundang-undangan yang lebih tinggi dengan mempetimbangkan kondisi sosial budaya masyarakat desa setempat.

Adanya peraturan desa ini digunakan oleh masyarakat desa, khususnya masyarakat Desa Sirapan untuk menertibkan kekisruhan yang sering terjadi saat penyelenggaraan acara hajatan berlangsung.

Banyaknya kekisruhan ataupun keonaran tersebut, membuat masyarakat ketika menyelenggarakan hajatan merasa tidak nyaman, tidak tentram, dan tidak damai. Serta dari keonaran atau kisruh tersebut juga menimbulkan kerugian yang harus ditanggung penyelenggara hajatan. Dengan adanya tindakan tersebut, maka kepala desa dan BPD membuat peraturan desa.

Penggunaan peraturan desa ini dimungkinkan dapat efektif dalam menangani kisruh atau keonaran dalam penyelenggaraan hajatan tersebut, serta dapat membuat jera pelaku-pelaku yang membuat kerusuhan itu. Dan akan terjadi perubahan ketika diterapkannya peraturan desa ini didalam masyarakat.

Ketertiban merupakan keadaan dimana dalam masyarakat itu serba teratur (Kamus Besar Bahasa Indonesia, 2008:1455), keadaan inilah yang sangat dibutuhkan bagi masyarakat. Dengan adanya keadaan yang tertib itu, akan tercipta keadaan yang kondusif. Dimana keadaan tertib yang diinginkan masyarakat akan terpenuhi dan tercipta dengan sendirinya. Tertib sendiri diartikan suatu konisi kehidupan di mana 
segala kegiatan berjalan sebagaimana semestinya, berjalan sebagaimana disepakati oleh semua orang, berjalan dalam norma-norma yang diberlakukan, berjalan berdasarkan aturan-aturan yang diberlakukan.

Keadaan tertib yang demikian sangatlah diinginkan oleh semua elemen masyarakat. Karena tujuan peraturan atau hukum itu adalah untuk menciptakan ketertiban dalam kehidupan bermasyarakat maka hukum sendiri dapat diartikan sebagai aturan-aturan tingkah laku guna terwujudnya ketertiban dalam kehidupan bermasyarakat. Ini berarti bahwa hukum diberlakukan untuk mencapai ketertiban, dan tercapainya ketertiban pada gilirannya akan mewujudkan rasa aman, rasa damai, tanpa ada konflik, tanpa ada sengketa, semua berjalan dalam lalu lintas yang teratur sesuai dengan jalur-jalur aturan yang diberlakukan.

Dengan demikian, ketertiban berkaitan erat dengan peraturan yang ada. Dengan tercapainya tujuan peraturan maka terwujudlah ketertiban yang diinginkan oleh semua masyarakat. Khususnya warga Desa Sirapan, karena ketika peraturan mengenai ketertiban penyelenggaraan hajatan benar-benar dilaksanakan dan dijalankan oleh warga Desa Sirapan, maka keinginan mewujudkan penyelenggaraan hajatan yang aman, tentram, dan damai tanpa ada konflik ataupun konaran dan kerusuhan dapat terlaksana dan terwujud. Untuk mewujudkannya semua elemen desa haruslah ikut berpartisipasi agar ketertiban yang diharapkan pada penyelenggaraan hajatan terwujud dan terlaksana dengan baik, yang mana aturannya terdapat pada Peraturan Desa nomor 3 tahun 2009 tentang ketertiban penyelenggaran hajatan.

Sebagaimana isi dari Peraturan Desa Nomor 3 Tahun 2009 peraturan yang ke 12 yaitu "Putusan lembaga desa orang yang punya hajat kalau ada yang merusak atau membuat kisruh atau onar diberi sanksi denda untuk mengganti biaya hajatannya" (Peraturan Desa Nomor 3 Tahun 2009, 2009:1).

Undang-Undang Nomor 6 Tahun 2014 tentang desa, penjelasan peraturan desa terdapat pada Pasal 69, dijelaskan pada ayat 
sebagaimana berbunyi "Peraturan sebagaimana dimaksud pada ayat (1) dilarang bertentangan dengan kepentingan umum dan/atau ketentuan peraturan perundangundangan yang lebih tinggi". Jadi peraturan desa yang dibuat tidak boleh bertentang dengan peraturanperaturan yang ada diatasnya. Sedangkan Peraturan Pemerintah yang mengatur mengenai Peraturan Desa ini, terdapat pada Peraturan Pemerintah Nomor 72 Tahun 2005 tentang desa $\mathrm{Bab} \mathrm{V}$ mengatur mengenai Peraturan Desa. Selanjutnya, Peraturan Daerah Kabupaten Atau Kota, terdapat pada Peraturan Daerah Kabupaten Madiun Nomor 13 Tahun 2007 tentang mekanisme perencanaan pembangunan desa dan kelurahan, Bab II mengenai perencanaan pembangunan desa dan kelurahan Pasal 2 ayat (1) (dalam Peraturan Daerah Kabupaten Madiun Nomor 13 Tahun 2007, 2007:4-5) yang berbunyi "Dalam rangka penyelenggaraan pemerintahan Desa/Kelurahan disusun perencanaan pembangunan Desa/Kelurahan sebagai satu kesatuan dalam sistem

perencanaan pembangunan daerah", serta ayat (2) yang berbunyi "Perencanaan pembangunan desa/kelurahan sebagaimana dimaksud pada ayat (1) disusun secara partisipasif oleh pemerintahan desa/ pemerintahan kelurahan sesuai dengan kewenangannnya”.

\section{Kajian tentang Peraturan Desa} Nomor 3 Tahun 2009 tentang Ketertiban Penyelenggaraan hajatan di Desa Sirapan Kecamatan Madiun Kabupaten Madiun

Peraturan Desa Nomor 3
Tahun 2009 tentang ketertiban
penyelenggaraan hajatan ini
sebagaimana bunyinya "Barang siapa
membuat onar atau kisruh atau
merusak ditempat hajatan diberi
sanksi denda untuk mengganti
biayanya". Adanya peraturan ini
karena diharapkan terwujudnya
suasana atau keadaan yang tertib,
aman serta damai dalam
penyelenggaraan hajatan di Desa
Sirapan. Peraturan ini dibuat
berdasarkan kondisi masyarakat pada
saat itu, dan berdasarkan keputusan
bersama antara Kepala Desa,


perangkat desa, serta tokoh masyarakat. Peraturan Desa ini juga bisa berasal dari usulan masyarakat desa sendiri. Peraturan desa nomor 3 tahun 2009 ini diharapkan dapat mewujudkan keinginan masyarakat mengenai keadaan yang diharapkan.

\section{Pengertian Ketertiban}

\section{Menurut}

Dirdjosiswoyo

Soedjono

(2010:134)

"ketertiban adalah suasana bebas yang terarah, tertuju kepada suasana yang didambakan oleh masyarakat, yang menjadi tujuan hukum”. Sedangkan Satjipto Rahardjo (2006:143-144) mengemukakan bahwa : Secara garis besar diawali dengan ide tentang ketertiban (order). Bagaimana keadaannya, komunitas manusia tidak akan dapat bertahan hidup tanpa ada ketertiban. Ketertiban ada untuk menjalankan masyarakat sehingga secara sosial menjadi produktif. Banyak faktor, elemen, dalam suatu masyarakat yang berkompetisi untuk memunculkan ketertiban itu. Dalam proses bernegara modern, harus diputuskan bagaimana sekalian faktor tersebut pada akhirnya membentuk suatu pola ketertiban.
Dalam bernegara modern itu dilakukan melalui legislasi dan hasilnya adalah hukum positif.

\section{Fungsi Ketertiban}

Masyarakat membutuhkan ketertiban serta keteraturan dan oleh karena itu membutuhkan hukum (Satjipto Rahardjo, 2006:168). Ini berarti bahwa hukum diberlakukan untuk mencapai ketertiban, dan tercapainya ketertiban pada gilirannya akan mewujudkan rasa aman, rasa damai, tanpa ada konflik, tanpa ada sengketa, semua berjalan dalam lalu lintas yang teratur sesuai dengan jalur-jalur aturan yang dibelakukan (Faried Ali dan Nurlina Muhidin, 2012:7). Adapun fungsi ketertiban berdasarkan uraian diatas, sebagai berikut:

a. Menumbuhkan budaya disiplin pada masyarakat, berarti dengan tumbuhnya budaya disiplin khususnya dalam mematuhi peraturan yang ada di lingkungan masyarakat, akan tercipta suasana yang aman dan tertib.

b. Menciptakan keadaan yang teratur dan damai, berarti dengan terciptanya keadaan yang teratur 
dan damai, akan terwujud pula ketertiban di masyarakat.

c. Memupuk rasa tanggung jawab pada diri masyarakat, dengan adanya rasa tanggung jawab pada diri masing-masing individu akan muncul rasa menghargai hak-hak orang lain, dan masing-masing individu akan bertanggungjawab terhadap apa yang telah mereka lakukan.

d. Menumpuhkan rasa menghargai pada orang lain, degan menghargai orang lain, tidak akan ada konflik ataupun sengketa antar masyarakat, yang ada rasa aman, damai dan toleransi antar masyarakat.

e. Menciptakan suasana lingkungan yang aman, keadaan aman akan tercipta apabila semua elemen masyarakat mematuhi peraturan yang ada, dan terwujudlah ketertiban di lingkungan masyarakat.

\section{Syarat Ketertiban}

Menurut Satjipto Rahardjo (2006:96) bahwa "hukum memang berbicara dan berurusan dengan ketertiban, hukum menempatkan diri sebagai penjaga, pengatur dan produsen ketertiban. Oleh karena itu ia tampil dengan membuat macammacam peraturan, suruhan dan larangan; hukum menjadi sebuah institusi normatif (normerende)".

Ketertiban Penyelenggaraan Hajatan di Desa Sirapan Kecamatan Madiun Kabupaten Madiun

Ketertiban yang berarti menciptakan keadaaan ataupun suasana yang teratur ataupun tertib sesuai dengan peraturan dan rapi, berusaha diwujudkan oleh masyarakat di Desa Sirapan. Berdasarkan aturan yang telah ada di desa, peraturan yang sudah menjadi kebiasaan warga Desa Sirapan ini, tetap dijalankan tanpa adanya peraturan yang tertulis. Adapun tata cara sebelum hajatan diselenggarakan, yaitu masingmasing masyarakat yang ingin mengadakan hajatan haruslah melapor atau meminta izin kepada desa atau perangkat desa yang bertugas saat akan menyelenggarakan hajatan pada waktu 15 hari sebelum acara hajatan tersebut diselenggarakan. Setelah mendapatkan surat dari desa, 
dilanjutkan membawa surat dari desa ke Polsek daerah setempat. Nantinya surat dari Polsek itu yang masyarakat gunakan sebagai pegangan ketika mereka mengadakan hajatan.

Dalam hal penyelenggaraan hajatan ini, hajatan yang dimaksud ialah penyelenggaraan acara tasyakuran pernikahan. Menurut Liza Zakaria, Fitri Liza, Fekum Ariesbowo (2007:10), definisi pernikahan merupakan "salah satu aspek dari kehidupan manusia, sedangkan dalam definisi sederhana, penikahan adalah suatu ikatan batin antara seorang pria dan wanita sebagai suami istri”. Serta dapat diartikan pula sebagai perhelatan yang sangat menguras perhatian, khususnya bagi sepasang calon mempelai" (Liza Zakaria, Fitri Liza, Fekum Ariesbowo, 2007:30).

Penyelenggaraan hajatan merupakan perhelatan yang besar bagi masyarakat, dengan demikian membutuhkan peraturan untuk membuat suasana atau keadaan ketika penyelenggaraan hajatan digelar tetap kondusif, aman, nyaman, tentram sesuai yang diinginkan penyelenggara maupun masyarakat sekitar. Dimulai dari mengantongi surat ijin kepada lembaga yang terkait sebagai pengatur keamanan yaitu pihak Kepolisian.

\section{METODOOGI PENELITIAN}

\section{Pendekatan dan Jenis Penelitian}

Peneliti dalam penelitian ini menggunakan pendekatan metode deskriptif kualitatif. Penelitian akan dilakukan di lapangan (Field research) yang bersifat deskriptif kualitatif.

Penelitian ini menggunakan pendekatan metode deskriptif kualitatif karena penelitian kualitatif sendiri merupakan penelitian yang menganalisis dan mendeskripsikan fenomena mengenai masalah sosial yang terjadi di masyarakat yang terjadi secara alami tanpa ada rekayasa. Bila dihubungkan dengan penelitian yang akan dilakukan Peneliti, yaitu implementasi Peraturan Desa Nomor 3 Tahun 2009 terhadap ketertiban penyelenggaraan hajatan. Maka penelitian ini juga akan mendeskripsikan maupun menganalisis masalah sosial yang terjadi di Desa Sirapan khususnya 
saat penyelenggaraan hajatan berlangsung yakni terjadi kerusuhan atau keonaran.

\section{Jenis Penelitian}

Jenis penelitian yang digunakan adalah kualitatif merupakan suatu penelitian yang ditujukan untuk mendeskripsikan dan menganalisis fenomena, peristiwa, aktivitas sosial, dan sikap, yang menghasilkan data deskriptif berupa kata-kata tertulis atau lisan dari orang-orang dan perilaku yang dapat diamati. Data ini biasanya diperoleh dari hasil wawancara dan bersifat subjektif sebab data tersebut dapat ditafsirkan lain oleh orang yang berbeda. Berdasarkan dengan jenis penelitiannya yaitu kualitatif, dan bila dihubungkan dengan penelitian ini, maka Peneliti akan menganalisis dan mendeskripsikan mengenai peristiwa yang terjadi di masyarakat Desa Sirapan berkaitan dengan implementasian Peraturan Desa Nomor 3 Tahun 2009 tentang Ketertiban Penyelenggaraan Hajatan dengan peristiwa kericuhan yang terjadi saat acara penyelenggaraan hajatan berlangsung.

\section{Sumber Data}

1. Sumber Data Primer

Dengan menggunakan teknik pengumpulan data berupa observasi dan wawancara. Sumber data primer dalam penelitian ini yaitu hasil wawancara dengan Kepala Desa dan Aparatur Desa, serta masyarakat Desa Sirapan Kecamatan Madiun Kabupaten Madiun yang menyelenggarakan hajatan tahun 2014 periode bulan Maret - Mei. Sumber data mengenai Peraturan Desa diperoleh dari Kepala Desa dan Aparatur Desa sebagai pembuat peraturan melalui wawancara. Sedangkan sumber data mengenai ketertiban penyelenggaraan hajatan diperoleh dari wawancara dengan masyarakat Desa Sirapan Kecamatan Madiun Kabupaten Madiun yang menyelenggarakan hajatan periode Maret - Mei.

2. Sumber Data Sekunder

Penelitian ini akan mengkaji tentang Implementasi Peraturan Desa Nomor 3 Tahun 2009 Terhadap Ketertiban Penyelenggaraan Hajatan di Desa Sirapan Kecamatan Madiun Kabupaten Madiun Tahun 2014. Maka, Peneliti dengan ini 
menentukan sumber data sekunder dalam penelitian ini adalah sebagai berikut:

a. Peraturan Perundang-undangan yang dijadikan sumber data sekunder, sebagai berikut:

1) Undang-Undang Dasar Negara Republik Indonesia Tahun 1945, terdapat pada Pasal 18B (2) yang berbunyi "Negara mengakui dan mengormati kesatuankesatuan masyarakat hukum adat beserta hak-hak tradisionalnya sepanjang masih hidup dan sesuai dengan perkembangan masyarakat dan prinsip Negara Kesatuan Republik Indonesia, yang diatur dalam undang-undang”. Serta Pasal 28J yang berbunyi "setiap orang wajib menghormati hak asasi manusia orang lain dalam tertib kehidupan bermasyarakat, berbangsa, dan bernegara".

2) Undang-Undang atau Peraturan Pemerintah Pengganti Undang-Undang, terdapat pada Undang-
Undang Nomor 6 Tahun 2014 tentang desa, penjelasan peraturan desa terdapat pada Pasal 69 ayat (2) berbunyi "Peraturan sebagaimana dimaksud pada ayat (1) dilarang bertentangan dengan kepentingan umum dan/atau ketentuan peraturan perundang-undangan yang lebih tinggi”.

3) Peraturan Pemerintah, terdapat pada Peraturan Pemerintah Nomor 72 Tahun 2005 tentang desa Bab V mengatur mengenai Peraturan Desa.

4) Peraturan Daerah Kabupaten Atau Kota, terdapat pada Peraturan Daerah Kabupaten Madiun Nomor 13 Tahun 2007 tentang mekanisme perencanaan pembangunan desa dan kelurahan, Bab II mengenai perencanaan pembangunan desa dan kelurahan Pasal 2 ayat (1) yang berbunyi "Dalam rangka penyelenggaraan pemerintahan 
Desa/Kelurahan disusun perencanaan pembangunan Desa/Kelurahan sebagai satu kesatuan dalam sistem perencanaan pembangunan daerah", serta ayat (2) yang berbunyi "Perencanaan pembangunan

desa/kelurahan sebagaimana dimaksud pada ayat (1) disusun secara partisipasif oleh pemerintahan desa/ pemerintahan kelurahan sesuai dengan kewenangannnya”.

Kemudian peraturan selanjutnya ialah Peraturan Desa Nomor 3 Tahun 2009 tentang ketertiban penyelenggaraan hajatan yang terdapat pada penyelenggaraan hajatan.

b. Dokumen-dokumen lain yang berkaitan dengan pelaksanaan implementasi Peraturan Desa Nomor 3 Tahun 2009 tentang ketertiban penyelenggaraan hajatan, misal berupa surat ijin mengadakan keramaian dari Polsek setempat; c. Foto-foto saat penyelenggaraan hajatan berlangsung.

\section{Teknik Pengumpulan Data}

1. Wawancara

Pelaksanaan wawancara menggunakan teknik interview terpimpin/guided interview yaitu interview yang dilakukan oleh pewawancara dengan membawa sederetan pertanyaan kepada interviewer atau seseorang yang dianggap tahu mengenai lingkup penelitian yaitu tentang Peraturan Desa Nomor 3 Tahun 2009 Tentang Ketertiban Penyelenggaraan Hajatan dan Ketertiban penyelenggaraan hajatan. Wawancara dilakukan dengan Kepala Desa, Aparatur Desa, dan masyarakat Desa Sirapan yang menyelenggarakan hajatan.

Kegiatan wawancara ini yang menjadi informan ialah Kepala Desa, 3 orang aparatur desa beserta 1 orang tokoh masyarakat yang memberi informasi mengenai Peraturan Desa Nomor 3 Tahun 2009 tentang ketertiban penyelenggaraan hajatan. Serta, 5 orang masyarakat Desa Sirapan yang menyelenggarakan 
hajatan pada tahun 2014 periode Maret - Mei.

2. Observasi

Mengadakan observasi menurut kenyataan, menggambarkannya dengan kata-kata secara cermat dan tepat apa yang diamati, mencatatnya dan kemudian mengolahnya. Dapat dikatakan dalam penelitian kualitatif, pedoman observasi hanya berupa garis-garis besar atau butir-butir umum kegiatan yang akan diobservasi. Rincian dari aspekaspek yang diobservasi dikembangkan di lapangan dalam proses pelaksanaan observasi.

Teknik observasi ini, yang akan dilakukan Peneliti saat observasi tentang implementasi Peraturan Desa Nomor 3 Tahun 2009 ialah mengamati sejauh mana pelaksanaan Peraturan Desa Nomor 3 Tahun 2009 saat penyelenggaraan hajatan berlangsung pada periode Maret Mei tahun 2014.

3. Dokumentasi

Menurut Sugiyono (2010:329) mengemukakan bahwa "dokumen merupakan catatan peristiwa yang sudah berlalu, dokumen bisa berbentuk tulisan, gambar, atau karya-karya monumental dari seseorang". Dengan dokumen ini peneliti akan mengambil data berupa foto-foto selama kegiatan pengamatan berlangsung, serta foto ketika penyelenggaraan hajatan berlangsung. Dengan adanya foto atau berupa gambar tersebut, akan digunakan sebagai pelengkap penelitian. Foto atau gambar diambil saat penyelenggaraan hajatan berlangsung maupun saat melakukan wawancara dengan informan. Adapun yang digunakan sebagai dokumen adalah sebagai berikut:

a. Peraturan desa nomor 3 tahun 2009 tentang ketertiban penyelenggaraan hajatan yang terdapat pada penyelenggaraan hajatan;

b. Dokumen-dokumen lain yang berkaitan dengan pelaksanaan implementasi Peraturan Desa Nomor 3 Tahun 2009 tentang ketertiban penyelenggaraan hajatan, misal berupa surat ijin mengadakan keramaian dari Polsek setempat;

c. Foto-foto saat penyelenggaraan hajatan berlangsung. 


\section{Teknik Analisis Data}

Teknik analisis data yang digunakan adalah teknis analisis data interaktif dari Milles dan Huberman. Miles and Huberman (dalam Sugiyono, 2010:337) mengemukakan bahwa "aktivitas dalam analisis data kualitatif dilakukan secara interaktif dan berlangsung secara terus menerus sampai tuntas, sehingga datanya sudah jenuh". Adapun beberapa aktifitas dalam analisis data tersebut ialah data reduction, data display, dan conclusion drawing/verification. Ketiga jenis analisis data tersebut dapat dijelaskan sebagai berikut (Sugiyono, 2010:338-345):

1. Data Reduction (Reduksi Data)

Reduksi data merupakan proses berpikir yang memerlukan kecerdasan, keluasan dan kedalaman wawasan yang tinggi. Sedangkan dalam penelitian ini, ketika Peneliti banyak memperoleh data atau temuan baru ketika melakukan wawancara maupun observasi di lapangan yang berkaitan dengan implementasi Peraturan Desa Nomor 3 Tahun 2009 terhadap ketertiban penyelenggaraan hajatan, maka
Peneliti bisa meminta bantuan teman atau orang yang dianggap ahli untuk membantunya.

\section{Data display (penyajian data)}

Dalam penelitian ini,data yang diperoleh ketika wawancara, obsevasi maupun dari dokumen saat penelitian dilaksanakan disajikan dengan urutan yang runtut. Dan memudahkan untuk memahami apa yang terjadi di lapangan berkaitan dengan implementasi Peraturan Desa Nomor 3 Tahun 2009 terhadap ketertiban penyelenggaraan hajatan tersebut.

\section{Conclusion Drawing/verivication}

Kesimpulan awal yang dikemukakan masih bersifat sementara, dan akan berubah bila tidak ditemukan buktibukti yang kuat pada tahap pengumpulan data berikutnya. Namun apabila kesimpulan awal didukung oleh data dan bukti yang terjamin dan konsisten saat Peneliti kembali kelapangan, maka kesimpulan yang dikemukakan merupakan kesimpulan yang kredibel. Apabila dilakukan permulan penelitian, apabila saat itu mendapatkan kesimpulan awal. Maka, pada pelaksanaan penelitian 
dengan melakukan wawancara dan observasi, kesimpulan yang bersifat sementara tadi harus dilengkapi dengan bukti-bukti yang kuat. Semisal dengan adanya foto atau gambar saat penyelenggaraan hajatan berlangsung. Atau gambar saat mewawancarai informan.

\section{Paparan Data dan Temuan} Penelitian

\section{a. Implementasi Peraturan Desa} Nomor 3 Tahun 2009

Hasil wawancara dari berbagai narasumber ini bertujuan untuk mengetahui bagaimana implementasi Peraturan Desa Nomor 3 Tahun 2009, dan adanya Peraturan Desa Nomor 3 Tahun 2009 tersebut dapat memberikan dampak yang positif atau sebaliknya saat acara penyelenggaraan hajatan berlangsung. Adapun hasil wawancaranya sebagai berikut:

1) Alasan pembuatan Peraturan Desa Nomor 3 Tahun 2009

Menurut Bapak Roy Ator Subroto selaku Kepala Desa berpendapat bahwa: "alasannya karna banyak terjadi keributan, kekisruhan, dan menyebabkan masyarakat tidak tenang. Sehingga masyarakat banyak yang mengusulkan untuk pembuatan Peraturan Desa tersebut" (wawancara hari senin tanggal 12 Mei 2014 pukul 10.30 WIB tempat kantor Desa Sirapan).

Selanjutnya pendapat dari Bapak

Fadlil, salah satu tokoh

masyarakat di Desa Sirapan

sebagai berikut:

"ya alasannya karena selama belum ada Peraturan Desa tersebut banyak perkelahian, banyak tawuran, banyak keonaran saat ada warga yang menyelenggarakan hajatan. Tentunya dengan banyak perkelahian, tawuran dan keornaran tersebut, masyarakat menjadi takut saat menyelenggarakan hajatan karena merasa kurang nyaman dan tenang. Karena hal-hal tersebut, Kepala Desa, perangkat desa beserta tokoh masyarakat mengadakan musyawarah dan terbentulah Peraturan Desa Nomor 3 Tahun 2009 tersebut" (wawancara hari selasa tanggal 13 Mei 2014 pukul 15.00 WIB 
tempat rumah Bapak Fadlil Desa Sirapan RT 04/01).

Berdasarkan paparan di atas mengenai alasan pemerintah Desa Sirapan membuat Peraturan Desa Nomor 3 Tahun 2009 dapat disimpulkan bahwa alasan pembuatan Peraturan Desa Nomor 3 Tahun 2009 dikarenakan banyak terjadi keributan saat acara hajatan berlangsung, sehingga masyarakat Desa Sirapan merasa tidak nyaman.

2) Tujuan dibuatnya Peraturan Desa Nomor 3 Tahun 2009

Menurut Bapak Roy Ator Subroto, selaku Kepala Desa di Desa Sirapan beliau mengatakan bahwa: "tujuannya itu supaya tercipta keadaan yang aman, tentram, tenang dan terkendali” (wawancara hari senin tanggal 12 Mei 2014 pukul 10.30 WIB tempat kantor Desa Sirapan).

Selanjutnya pendapat dari salah satu tokoh masyarakat yaitu bapak Fadlil bahwa: "ya seperti saya katakan tadi, tujuannya supaya tercipta keadaan yang nyaman dan tenang. Dengan keadaan itu nantinya masyarakat merasa tidak takut lagi saat akan menyelenggarakan hajatan" (wawancara hari selasa tanggal 13 Mei 2014 pukul 15.00 WIB tempat rumah Bapak Fadlil Desa Sirapan RT 04/01).

Berdasarkan hasil wawancara mengenai tujuan dibuatnya Peraturan Desa Nomor 3 Tahun 2009 dapat disimpulkan bahwa tujuan dibuatnya peraturan ini untuk menciptakan keadaan yang aman, nyaman, tentram, dan terkendali.

3) Yang diatur dalam Peraturan Desa Nomor 3 Tahun 2009 Menurut penuturan Bapak Kepala Desa yaitu Bapak Roy Ator Subroto bahwa: "pada dasarnya isi dari Peraturan Desa Nomor 3 Tahun 2009 yaitu ada 12 poin. 12 poin tersebut sebagai berikut:

(a) Peraturan Desa Sirapan atau adat desa seperti tahun lalu,

(b) surat menyurat dikenakan membayar administrasi@Rp $2.000,-$

(c) surat menyurat jual beli tanah atau rumah dan lain-lain 
diharuskan atau dikenakan

membayar sumbangan ke desa 3\% kalau dalam desa kalau keluar desa 5\%,

(d) surat menyurat talak atau rujuk@Rp 5.000,- atau cerai Rp 10.000,- ,

(e) surat orang lain desa memakamkan jenazah di Desa Sirapan di kenakan menyumbang perbaikan makam @ Rp 50.000,-,

(f) orang luar desa tidak boleh ngijing di makam,

(g) tali asih PJS Kepala Desa $30 \% \times 2$ tahun selama 2 tahun namun di minta 1 tahun 60\%, tahun 2009 berasal darri tanah bengkok atau kas desa,

(h) honor PJS Kepala Desa 40\% tahun 2009 dari bengkok dari tanah kas desa,

(i) administrasi atau surat menyurat atau retribusi surat keterangan umum @ Rp $2.000,-$,

(j) administrasi atau surat menyurat atau retribusi surat nikah Rp 5.000,- , (k) administrasi atau surat menyurat atau retribusi surat cerai @Rp 10.000,-,

(1) putusan lembaga desa yang punya hajat kalau ada yang merusak atau membuat kisruh atau onar diberi sanksi denda untuk mengganti biaya hajatan.

Sedangkan yang diteliti poin yang terakhir itu, dalam Peraturan Desa ini sifatnya masih umum belum ada penjabarannya. Biasanya di desa itu kalau penjabaran dari aturan-aturan tersebut di sesuaikan dengan adat yang telah ada" (wawancara hari senin tanggal 12 Mei 2014 pukul 10.30 WIB tempat kantor Desa Sirapan).

Selanjutnya pendapat Bapak Fadlil selaku tokoh masyarakat mengatakan bahwa: "yang diatur dalam Peraturan Desa Nomor 3 Tahun 2009 itu kalau semuanya saya tidak hafal isinya apa saja, tapi diantaranya ya jelas mengenai ketertiban saat penyelenggaraan hajatan berlangsung yang membuat keonaran diberi sanksi itu, kemudian mengenai larangan 
bagi orang yang lain desa saat memakamkan di makam Desa Sirapan, tidak boleh mengijing makam. Dalam Peraturan Desa Nomor 3 Tahun 2009 ini hanya peraturan yang umum saja, nanti isinya lebih lanjut ya disesuaikan dengan adat di desa" (wawancara hari selasa tanggal 13 Mei 2014 pukul 15.00 WIB tempat rumah Bapak Fadlil Desa Sirapan RT 04/01).

Berdasarkan paparan di atas mengenai apa saja yang diatur dalam Peraturan Desa Nomor 3 Tahun 2009 dapat disimpulkan bahwa pada dasarnya yang diatur dalam Peraturan Desa Nomor 3 Tahun 2009 ini terdapat 12 poin atau 12 ayat, dalam penelitian ini yang akan dibahas yaitu poin ke 12 yakni mengenai putusan lembaga desa yang punya hajat kalau ada yag merusak atau membuat kisruh atau onar diberi sanksi denda untuk mengganti biaya hajatan. Dalam Peraturan Desa Nomor 3 Tahun 2009 hanya memuat aturan umum, sedangkan pemaparan ataupun penjelasannya disesuaikan dengan adat istiadat desa. b. Ketertiban penyelenggaraan hajatan di Desa Sirapan Kecamatan Madiun Kabupaten Madiun

Hasil wawancara mengenai ketertiban penyelenggaraan hajatan di Desa Sirapan Kecamatan Madiun Kabupaten Madiun sebagai informannya, Peneliti akan melakukan wawancara dengan masyarakat Desa Sirapan yang menyelenggarakan hajatan pada bulan Maret - Mei 2014. Adapun hasil wawancara sebagai berikut:

1) Makna ketertiban

Menurut pendapat Ibu Tami salah seorang masyarakat Desa Sirapan bahwa: "ketertiban itu keadaan yang disiplin" (wawancara hari senin tanggal 16 Juni 2014 pukul 10.00 WIB tempat rumah ibu Tami Desa Sirapan RT 05/RW 04).

Penuturan Bapak Supadi mengenai makna ketertiban adalah: "ketertiban itu kedisiplinan, tertib dalam segala bidang" (wawancara hari senin tanggal 16 Juni 
2014 pukul 15.30 WIB tempat rumah bapak Supadi Desa Sirapan RT 04/RW 01). Ibu Sadikem juga mengemukakan bahwa: "ketertiban merupakan suatu peraturan yang harus dijalankan dengan baik dan benar" (wawancara hari rabu tanggal 18 Juni 2014 pukul 09.15 WIB tempat rumah ibu Sadikem Desa Sirapan RT 02/RW 01).

Selanjutnya menurut Bapak Sumardi bahwa: "ketertiban bermakna aturan yang dibuat supaya segala sesuatunya berjalan teratur" (wawancara hari rabu tanggal 18 Juni 2014 pukul 18.30 WIB tempat rumah bapak Sumardi Desa Sirapan RT 04/RW 01). Berdasarkan paparan di atas mengenai makna ketertiban dapat disimpulkan bahwa makna ketetiban bagi masyarakat yaitu keadaan yang disiplin, tertib dalam segala bidang sehingga segala sesuatu berjalan dengan teratur.
2) Adanya ketertiban dalam penyelenggaraan kegiatan hajatan dapat memberikan dampak positif

Menurut Ibu Tami bahwa: "iya dapat memberikan, supaya tercipta suasana yang aman" (wawancara hari senin tanggal 16 Juni 2014 pukul 10.00 WIB tempat rumah ibu Tami Desa Sirapan RT 05/RW 04).

Sedangkan menurut penuturan Bapak Supadi bahwa: "iya, menjadikan keadaan yang tenang dan aman" (wawancara hari senin tanggal 16 Juni 2014 pukul 15.30 WIB tempat rumah bapak Supadi Desa Sirapan RT 04/RW 01).

Ibu Sadikem juga menjelaskan bahwa: "ya, karena apabila ketertiban itu dapat dijalankan dengan baik dan benar" (wawancara hari rabu tanggal 18 Juni 2014 pukul 09.15 WIB tempat rumah ibu Sadikem Desa Sirapan RT 02/RW 01).

Selanjutnya Bapak Sumardi mengatakan bahwa: "bisa jadi, 
jika ada kesadaran dari masyarakat untuk menjaga ketertiban yang telah dibuat sehingga tercipta keadaan yang aman dan kondusif" (wawancara hari rabu tanggal 18 Juni 2014 pukul 18.30 WIB tempat rumah bapak Sumardi Desa Sirapan RT 04/RW 01).

Berdasarkan paparan di atas mengenai dampak positif yang diberikan dengan adanya ketertiban dalam penyelenggaraan hajatan dapat disimpulkan bahwa Adanya ketertiban dalam penyelenggaraan hajatan bagi masyarakat Desa Sirapan memberikan dampak yang positif, yaitu terciptanya keadaan yang aman, nyaman, dan kondusif.

\section{Temuan Data}

1. Keadaan yang tidak terkontrol saat penyelenggaraan hajatan berlangsung sebelum adanya Peraturan Desa Nomor 3 Tahun 2009 ,
Karena tidak adanya dasar atau aturan yang jelas mengenai ketertiban saat penyelenggaraan hajatan, menyebabkan keadaan yang tidak terkontrol dan keadaan yang tidak kondusif. Hal ini tentunya membuat masyarakat merasa tidak nyaman, dengan alasan itu masyarakat mengusulkan untuk dibuatkan aturan mengenai ketertiban saat penyelenggaraaan hajatan.

2. Kurangnya pengetahuan masyarakat mengenai Peraturan Desa Nomor 3 Tahun 2009, Berdasarkan wawancara yang telah dilaksanakan, bahwa masyarakat sebenarnya kurang mengetahui Peraturan Desa Nomor 3 Tahun 2009 khusunya poin ke 12 mengenai mengenai putusan lembaga desa yang punya hajat kalau ada yag merusak atau membuat kisruh atau onar diberi sanksi denda untuk mengganti biaya hajatan. Kurangnya pempublikasian mengenai peraturan, bahkan terdapat masyarakat yang sama sekali tidak mengetahui apa itu Peraturan Desa Nomor 3 Tahun 2009. 
Di lapangan Peneliti dapat mengetahui bahwa masyarakat Desa Sirapan merupakan masyarakat yang sering menyelenggarakan kegiatan hiburan dari musik dangdut, hadroh modern ataupun karawitan, yang dilaksanakan saat penyelenggaraan hajatan ataupun pada acara-acara tertentu.

Menurut teori dan hasil wawancara bahwa tujuan adanya ketertiban yakni mewujudkan rasa aman, damai dan tidak ada konflik, sama halnya dengan harapan yang diinginkan masyarakat Desa Sirapan setelah adanya Peraturan Desa Nomor 3 Tahun 2009 khususnya mengenai ketertiban penyelenggaraan hajatan. Terciptanya keadaan yang aman dan tidak ada keributan, itu yang terjadi pada Desa Sirapan saat ini. Dengan demikian, dapat disimpulkan bahwa tujuan adanya ketertiban ini dapat terwujud di Desa Sirapan, keadaan yang diharapakan dapat terwujud, tentunya disertai dengan peran serta dan kesadaran masyarakat dalam implementasi Peraturan
Desa Nomor 3 Tahun 2009 khususnya mengenai ketertiban penyelenggaraan hajatan.

\section{Simpulan}

Berdasarkan analisis data yang telah di laksanakan, maka dapat disimpulan sebagai berikut: Bahwa Peraturan Desa Nomor 3 Tahun 2009 khususnya mengenai ketertiban penyelenggaraan hajatan telah di laksanaakan sesuai aturan sehingga tidak mengganggu ketertiban di dalam penyelenggaraan hajatanhajatan yang diadakan masyarakat Desa Sirapan.

Hal ini dapat dibuktikan, bahwa setiap di laksanakannya penyelenggaraan hajatan di Desa Sirapan selalu berjalan dengan lancar dan tidak menimbulkan keributankeributan yang dapat mengganggu ketenangan masyarakat Desa Sirapan saat menyelenggarakan hajatan. Sehingga, penyelenggaraan hajatan dapat berjalan dengan baik, tertib, lancar, dan aman serta keadaan menjadi kondusif dan terkendali. Ini disebabkan karena adanya kesadaran dan peran aktif masyarakat dalam pelaksanaan Peraturan Desa Nomor 3 
tahun 2009 khususnya mengenai ketertiban penyelenggaraan hajatan dan kerjasama yang baik antara masyarakat Desa Sirapan dengan perangkat desa. Dengan demikian, tujuan dari ketertiban yakni terwujudnya rasa aman, rasa damai, tidak ada sengketa maupun tidak ada konflik dapat terwujud dan terlaksana dengan baik. Dan tercipta keadaan aman saat penyelenggaraan hajatan berlangsung di Desa Sirapan.

\section{Saran}

\section{Bagi Perangkat Desa}

Peraturan Desa mengenai ketertiban penyelenggaraan hajatan akan terlaksana dengan baik dan tujuan Peraturan Desa akan terwujud apabila perangakt desa melaksanakan Peraturan desa Nomor 3 Tahun 2009 khususnya mengenai ketertiban penyelenggaraan hajatan sesuai dengan aturan. Dan perlunya penjabaran lebih lanjut mengenai aturan ketertiban penyelenggaraan hajatan yakni keributan yang terjadi setelah penyelenggaraan hajatan berlangsung, dikarenakan masih adanya keributan karna pengaruh minuman keras. Serta adanya kerjasama yang baik antara perangkat desa (lembaga pemerintahan desa) dengan masyarakat desa. Selain itu, perangakat desa harus memberikan sosialisasi ataupun pemeberitahuan kepada masyarakat Desa Sirapan mengenai Peraturan Desa Nomor 3 tahun 2009 khususnya mengenai ketertiban penyelenggaraan hajatan.

\section{Bagi Masyarakat}

Peran aktif dan kesadaran masyarakat sangat berpengaruh dalam terwujudnya tujuan ketertiban penyelenggaraan hajatan. Sehingga kesadaran masyarakat akan membuat masyarakat melaksanakan Peraturan Desa Nomor 3 Tahun 2009 khususnya mengenai ketertiban penyelenggaraan hajatan. Diharapakan masyarakat dengan penuh kesadaran melaksanakan Peraturan Desa Nomor 3 Tahun 2009 khususnya mengenai ketertiban penyelenggaraan hajatan, demi mewujudkan Desa Sirapan yang aman saat penyelenggaraan hajatan. 
DAFTAR PUSTAKA

Amin Suprihatini. 2007. Pemerintahan Desa dan Kelurahan. Klaten: Cempaka Putih.

Azam Awang. 2010. Implementasi Pemberdayaan Pemerintah Desa. Yogyakarta: Pustaka Pelajar.

Burhan Bungin. 2007. Penelitian Kualitatif. Jakarta: Prenada Media Group.

Didik Sukriono. 2010. Pembaharuan Hukum Pemerintah Desa. Malang: Setara Press.

Eni Anjani. 2007. Desaku Masa Depanku. Klaten: Cempaka Putih.

Faried A, Nurlina M. 2012. Hukum Tata

Pemerintahan Heteronom dan Otonom. Bandung: Rafika Aditama.

Hanif Nurcholis. 2011. Pertumbuhan \& Penyelenggaraan Pemerintahan Desa. Jakarta: Grasindo.

\section{Teori dan} Praktik Pemerintahan dan Otonomi Daerah. Jakarta: Grasindo.

Jimly Asshiddiqie. 2011. Pengantar Ilmu Hukum Tata Negara. Jakarta: RajaGrafindo Persada.
Kaelan. 2012. Problem Epistemologis Empat Pilar Berbangsa dan Bernegara. Yogyakarta: Paradigma.

Kamus Besar Bahasa Indonesia. 2008. Jakarta. Gramedia Pustaka Utama.

Lexy. J. Moleong. 2012. Metodologi Penelitian Kualitatif. Bandung: Remaja Rosdakarya Offset

Liza Z, dkk. 2007. Let's Get Married. Depok: Penebar Swadaya.

Margono. 2010. Metodologi Penelitian Pendidikan. Jakarta: Rineka Cipta.

Mohammad Taufik, Sarman. 2011. Hukum Pemerintahan Daerah di Indonesia. Jakarta: Rineka Cipta.

Nana Syaodih. 2012. Metode Penelitian Pendidikan. Bandung: Remaja Rosdakarya Offset.

Nyoman Kutha. 2010. Metodologi Penelitian. Yogyakarta: Pustaka Belajar.

Peraturan Daerah Kabupaten Madiun Nomor 13 Tahun 2007 tentang Mekanisme Perencanaan Pembangunan Desa dan Kelurahan.

Peraturan Pelaksanaan Pemerintah Daerah. 2006. Jakarta: Eka Jaya. 
Sadu W, Irwan T. 2006. Prospek Pengembangan Desa. Bandung: FokusMedia.

Undang-undang Dasar Republik Indonesia Tahun 1945.

Satjipto Rahardjo. 2006. Hukum Dalam Jagat Ketertiban. Jakarta: Uki Press.

Soedjono Dirdjosiswoyo. 2010. Pengantar Ilmu Hukum. Jakarta: Raja Grafindo Persada

Suharsimi Arikunto. 2006. Prosedur Penelitian. Jakarta: Asdi Mahasatya.

Sugiyono. 2010. Metode Penelitian Pendidikan Pendekatan
Kuantitatif, Kualitatif, dan $R \& D$. Bandung: Alfabeta.

- 2013. Memahami
Penelitian Kualitatif. Bandung: Alfabeta.

Tri Haryanto. 2007. Мепијu Masyarakat Swadaya dan Swakelola. Klaten: Cempaka Putih.

Undang-undang Nomor 6 Tahun 2014 Tentang Desa (http://www.kemendagri.go.i d/pdf, diunduh tanggal 20 April 2014 Pukul 19.00).

\begin{tabular}{crc} 
Undang-undang & \multicolumn{2}{r}{ Pembentukan } \\
Peraturan & $\begin{array}{r}\text { Perundang- } \\
\text { undangan }\end{array}$ & (Undang-Undang \\
Republik & Indonesia & Nomor \\
12 Tahun 2011). & 2012. \\
Jakarta: Sinar Grafika. &
\end{tabular}

